ENTREPRENEURSHIP AND SUSTAINABILITY ISSUES

ISSN 2345-0282 (online) http://jssidoi.org/jesi/

2021 Volume 8 Number 4 (June)

http://doi.org/10.9770/jesi.2021.8.4(46)

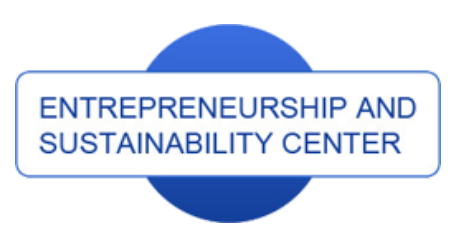

Publisher

$\underline{\text { http://jssidoi.org/esc/home }}$
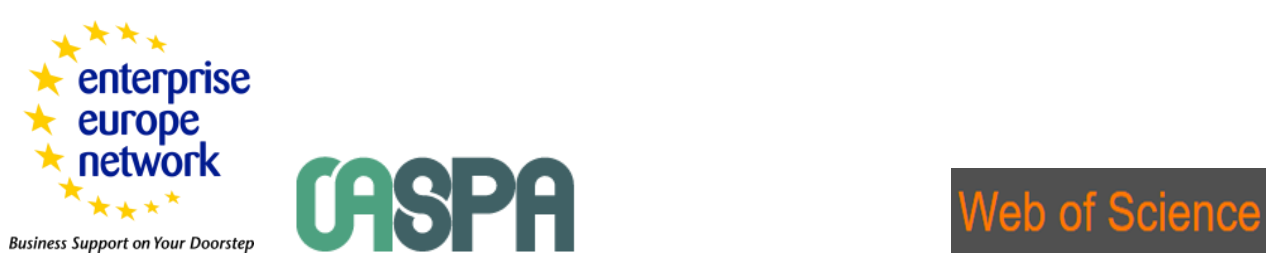

I Clarivate

Analytics

\title{
EFFICIENCY OF USING THE POTENTIAL OF SMALL BUSINESS IN ENSURING SUSTAINABLE
} ECONOMIC GROWTH

\author{
Irina Skuratovych ${ }^{1 *}$, Nataliia Lytvyn ${ }^{2}$, Iryna Panova ${ }^{3}$, Ievgen Ovcharenko ${ }^{4}$, Olena Hryhorevska ${ }^{5}$ \\ ${ }^{1 *}$ Yaroslav Mudryi National law University, Pushkinskaya str., 77, Kharkiv, 61024, Ukraine \\ ${ }^{2}$ State Fiscal Service University of Ukraine, University str., 31, Irpin, Kyiv region, 08201, Ukraine \\ ${ }^{3}$ Kharkiv National University of Internal Affairs, Lev Landau Avenue, 27, Kharkiv, 61000, Ukraine \\ ${ }^{4}$ Volodymyr Dahl East Ukrainian National University, 59-a Tsentralnyi Ave., Sievierodonetsk, 93400, Ukraine \\ ${ }^{5}$ Kyiv National University of Technology and Design, Nemyrovycha-Danchenka Street, 2, Kyiv, 01011, Ukraine \\ E-mail: ${ }^{1 *}$ skuratovych@i.ua (Corresponding author)
}

Received 15 March 2021; accepted 7 May 2021; published 30 June 2021

\begin{abstract}
In Ukraine, small business has not yet become the foundation of the national economy and an important factor of socioeconomic development. The negative trends in the activities of small business in Ukraine include a decrease in the number of small enterprises, reduction of the number of employees in small enterprises, and worsening of financial results of their activities. The purpose of the paper is to sum up theoretical and methodical foundations and develop scientific and practical recommendations for improving the efficiency of using the potential of small business in ensuring sustainable economic growth. In the process of the study, the following general and special methods were used: dialectical method; method of system analysis; method of graphic analysis; and method of logical generalization of results. Improvement of the organizational and economic relations of small enterprises with large and medium enterprises was determined as one of the directions of increasing the efficiency of small business potential, and the formation of an integration model of business associations as a set of possible forms of interaction of small, medium and large enterprises and areas of integration was suggested. The role of small business in reducing labor emigration as a form of self-employment and employment was studied. Specifics of innovative activity in the small business sector in Ukraine were considered. In order to increase the efficiency of small business potential, the introduction of innovative incubators was suggested. It is advisable to use the practical results of the study for intensification of business activities, for the purpose of increasing the efficiency of using the potential of small business in ensuring sustainable economic growth of the country.
\end{abstract}

Keywords: sustainable economic development; innovative business; potential; labor migration; efficiency

Reference to this paper should be made as follows: Skuratovych, I., Lytvyn, N., Panova, I., Ovcharenko, I., Hryhorevska, O. 2021. Efficiency of using the potential of small business in ensuring sustainable economic growth. Entrepreneurship and Sustainability Issues, 8(4), 742-756. http://doi.org/10.9770/jesi.2021.8.4(46)

JEL Classifications: K22, L21 


\section{ENTREPRENEURSHIP AND SUSTAINABILITY ISSUES}

ISSN 2345-0282 (online) http://jssidoi.org/jesi/

2021 Volume 8 Number 4 (June)

http://doi.org/10.9770/jesi.2021.8.4(46)

\section{Introduction}

In the difficult conditions of building a socially oriented economy of Ukraine, one of the main tasks is the development of small business, the expansion of business initiative of the population of both the country as a whole and its separate regions. In terms of the pace of small business development, Ukraine lags far behind the leading countries of the world that stimulate and support small and medium enterprises, which contributes to their innovative development, improving the quality and competitiveness of products, improving social living standards.

In the structure of the national economic system, small business, compared to medium and large business, can rightly be considered as the most important component that can determine the rate of economic growth, contribute to strengthening the competitive environment and solving social problems. However, the realities of the economy of Ukraine and its regions indicate negative trends in the main characteristics of small business. In its turn, the level of development of small business depends on the formation, implementation and level of use of its potential. In this regard, the issues of scientific substantiation of the directions of increasing the efficiency of using the potential of small business in ensuring sustainable economic growth of the country are actualized.

In modern models of market economies of developed countries, small business is a significant sector, which contribution to production is more than $50 \%$ of GDP, and the number of employees in this sector reaches $50 \%-$ $75 \%$ of total employment (Baker et. al (2021)). Therefore, all economically developed countries support and stimulate the development of small and medium enterprises, which contributes to the growth of their products, improving their quality and competitiveness, intensification of innovation and investment processes in the business sphere.

\section{Literature review}

The attitude to business activity formed in the country, the business activity itself and the desire of individuals to carry out business activity are the basis for the potential of small enterprises (SEP). The attitude to business reflects the general attitude of the population to businessmen and business activity (Amato et. al (2017)). If in a country there are people who can not only anticipate new business opportunities, but also have the necessary knowledge and experience, this will both significantly affect the level of SEP and contribute to the economic growth of the country as a whole.

The attitude to business in society affects business activity, and vice versa - the image of successful businessmen contributes to a positive attitude of the population to business. The level of business activity, efficiency of use of SEP in the future will be higher when today there will be more people who want to create their own business, carriers of business ideas, innovators capable of producing new products to meet the individual needs of specific consumers (Alsafadi et. al (2020)).

Over a long period of studies, scientists have proven the relationship between economic growth and business potential (Audretsch et. al (2015)). In underdeveloped countries, there are a large number of small firms that provide consumer services in the local market (Summers (2015)). At the same time, employers do not create additional jobs, which encourages the population to start their own business. If a country is characterized by political and economic stability, which contributes to the development of large business, a decrease in the growth rate of small and medium enterprises is observed (Newman et. al (2017)). But after the country reaches a slightly higher level of development, there is an intensification of business activity due to the improvement of the business environment, changes in social values, the drive of the population to making independent decisions and selfrealization. Thus, it is the business behavior of the individual who creates a business and manages it is the basis of business potential. 


\section{ENTREPRENEURSHIP AND SUSTAINABILITY ISSUES}

ISSN 2345-0282 (online) http://jssidoi.org/jesi/

2021 Volume 8 Number 4 (June)

http://doi.org/10.9770/jesi.2021.8.4(46)

At the same time, a businessman, acting in real socio-economic conditions, will not be able to fully implement his business ideas without adequate conditions, appropriate legal, economic, infrastructural support. Business environment is a system set of such conditions, which level of favorableness is determined by the influence of a large number of different factors (Audretsch et. al (2015)). The main such factors include political and legal, economic, institutional, scientific and technical, informational, social factors (Henrekson \& Sanandaji (2020)).

It should be noted that the potential of small business, as an economic category, can be considered from different points of view while emphasizing the properties, regularities, principles and factors of its formation and use. The main properties and regularities of formation of business potential should include:

- the relationship and balance of the elements of the potential, which must function simultaneously and in aggregate (Canales (2016));

- the alternative elements of the potential, which can to some extent replace each other (Colpan \& Jones (2016));

- the dynamics of the potential formation, which makes it impossible to determine it by way of mechanical addition of constituent elements (Staniewski (2016));

- the business potential can be independently transformed with the emergence of new constituent elements;

- flexibility, adaptability and stability of the potential, which will help preserve its integrity in the implementation of external influences (Dana (2017)).

However, paying tribute to the achieved results, we can identify a number of insufficiently addressed issues of formation, use and development of small business potential as a strategic factor of socio-economic changes in economic growth. The scientific and practical relevance of these issues conditioned the selection of the study subject.

\section{Research Methodology and Data}

The theoretical and methodical basis of the paper are scientific works on the problems of business development, formation and activation of the business potential of small businesses. In the process of the study, the following general and special methods were used: dialectical method - to identify regularities, principles and factors that promote the development of small business potential; system analysis - to provide insight into the components of the potential of small business; graphical analysis - to schematically reflect the generalized theoretical and practical foundations of the study; logical generalization of results - to develop recommendations for improving the efficiency of using the business potential of small businesses in ensuring sustainable economic growth.

The information base of the study consisted of: legislative and normative legal acts of the Verkhovna Rada and the Cabinet of Ministers of Ukraine, normative documents of ministries and government agencies; official data of the State Statistics Service of Ukraine and the Main Department of Statistics; materials published in scientific and periodic publications, on the Internet, as well as data obtained by the author in the process of his own studies.

The purpose of the paper is to generalize theoretical and methodical foundations and develop scientific and practical recommendations for improving the efficiency of using the potential of small business in ensuring sustainable economic growth.

\section{Results}

Under the influence of globalization, informatization, intellectualization of the entire economic space and its individual areas, the importance of small business is increased and complicated in modern economic systems. Such traditional functions of this sphere of economic activity as mobility of production, development of the competitive environment, formation of a middle class, and creation of additional jobs remain determinant. Along with this, the formation of an open economy, increasing innovation potential, ensuring sustainable economic growth and establishing social stability acquire a primary value. 


\section{ENTREPRENEURSHIP AND SUSTAINABILITY ISSUES}

ISSN 2345-0282 (online) http://jssidoi.org/jesi/

2021 Volume 8 Number 4 (June)

http://doi.org/10.9770/jesi.2021.8.4(46)

It should be noted that achievement of a new stage of transformation of small and medium enterprises is an important indicator of the state of development of the business environment in Ukraine. The main indicators of its presence in the structure of the national economy are commensurate with the indicators of developed countries of the world. The share of small and medium enterprises in the tax formation of the state budget revenues is about $50 \%$, and their share in VAT averages $60 \%$. This allows to conclude that small and medium enterprises in Ukraine are gradually becoming an important factor in socio-economic development providing the most part of jobs, GDP of the country, and tax revenues to the consolidated budget.

In Ukraine, there were adopted a number of normative and legislative documents regulating the activities, accounting, reporting and taxation of small businesses, including:

1) Law of Ukraine "On state support of small business". With amendments (2000));

2) Economic Code of Ukraine. With amendments (2003));

3) Tax Code of Ukraine. With amendments (2011)).

In the current normative and legislative documents, there are several signs of identification of small businesses for different purposes. Thus, the Law of Ukraine "On state support of small business" With amendments (2000) defines the legal basis for state support of small business. In Art. 1 of this law, a definition of the concept of small business entity is provided, i.e., it is determined, which business entities belong to the category of small business entities, namely: individuals registered in the established order as a business entity; legal entities, business entities of any organizational and legal form and form of ownership, in which the average number of employees for the reporting period (calendar year) does not exceed 50 persons, and the annual gross income does not exceed UAH $70 \mathrm{mln}$.

According to Art. 63 of the Economic Code of Ukraine. With amendments (2003)), With amendments (2003)). According to this document, a small enterprise is one that has an average number of employees per year of no more than 50 persons, and their annual gross income does not exceed UAH $70 \mathrm{mln}$.

According to the Tax Code of Ukraine. With amendments (2011)), small enterprises include those, in which the amount of income of each tax reporting period cumulatively from the beginning of the year does not exceed three million hryvnias and accrued wages (income) for each month of the reporting period of employees who are in an employment relationship with the taxpayer, is not less than two minimum wages, the amount of which is established by law, and which meet one of these criteria: created in the order established by law after April 1, 2011; operating, in which during three consecutive previous years (or during all previous periods, if less than three years have passed since their creation), the annual amount of income is declared in the amount not exceeding three million hryvnias, and in which the average number of employees during this period did not exceed 20 persons; which were registered as a single tax payer in the order established by by law in the period before the the Tax Code entered into force, and in which the volume of income from sales of products (goods, works, services) amounted to one million hryvnias and the average number of employees was up to 50 persons in the last calendar year.

For small enterprises of Ukraine, the main economic and legal forms of business organization are private and collective ones. Different legal forms of small enterprises have special mechanisms of operation. Thus, if we consider various aspects of the operation of a private enterprise, limited liability company, and a joint stock company, the differences between them are observed on such grounds as the nature of ownership, management system, internal control functions, the order of profit distribution.

It should be noted that the condition of the commodity market in Ukraine, on which small businesses operates, differ significantly from that of developed countries. If the developed market relations are characterized by the 
predominant influence of demand with a rapid response to it, the priority of private property, developed market infrastructure, efficiency and detail of legislation, availability of production factors, information openness, minimal criminalization, Ukrainian small business operates in more complex conditions, which determine its inherent features. The most significant features, which distinguish it from small business in most countries are the following:

- low technical and technological level with significant innovation potential;

- low management level, lack of knowledge, experience and culture of market relations;

- striving for maximum independence when most foreign small businesses operate under conditions of franchise, subcontracting, etc;

- combination of several types of activity within one small enterprise, impossibility in most cases to be guided by one-product model of development;

- lack of self-organization system and insufficient infrastructure to support small business;

- lack of complete and reliable information on the market condition and situation;

- lack of state financial and credit support;

- low level of information, consulting and training services;

- high level of adaptability to the difficult economic situation complicated by management disorganization and the growing criminalization of society;

- distrust of Western partners and so far a negative attitude of the population to businessmen.

Labor migration is one of the most serious state problems in Ukraine, and urgent measures are needed to address it. Lack of clear principles of state migration policy, a narrow range of countries, with which agreements on mutual employment of citizens have been concluded, insufficient level of social protection of workers necessitate the search for new means of combating labor migration.

In Ukraine, the share of GDP generated by small businesses ranges from $7.7 \%$ to $16.6 \%$ (Expenditure on innovation of industrial enterprises by areas of innovation activity (2020)), depending on the study period, the source of information and the accuracy of the calculations. In the EU member states, the average share of GDP generated by small businesses exceeds $50 \%$, and the average share of the population employed in small business entities (SBEs) reaches $70 \%$ (Table 1).

Table 1. Characteristics of GDP and employment in small business in the world countries

\begin{tabular}{|c|c|c|}
\hline Country & $\begin{array}{c}\text { Share of GDP of a country generated by small } \\
\text { business entities }\end{array}$ & $\begin{array}{c}\text { Share of the population employed in small business } \\
\text { entities }\end{array}$ \\
\hline Ukraine & $7.7 \%-16.6 \%$ & Less than $11 \%$ \\
\hline Spain & \multirow{3}{*}{ More than $50 \%$} & \multirow{3}{*}{$46 \%-73 \%$} \\
\hline Germany & & \\
\hline France & & \\
\hline Switzerland & $51 \%$ & $69.1 \%$ \\
\hline Japan & $52 \%-55 \%$ & $85 \%$ \\
\hline India & - & $80 \%$ \\
\hline China & $60 \%$ & $75 \%$ \\
\hline United Kingdom & $50 \%-53 \%$ & $49 \%$ \\
\hline Singapore & $\begin{array}{l}\text { GDP growth at the cost of small business } \\
\text { entities at the level of } 5 \%-6 \% \text { per year }\end{array}$ & - \\
\hline Canada & $43 \%$ & $65 \%$ \\
\hline USA & $50 \% \%-52 \%$ & $60 \%$ \\
\hline
\end{tabular}

Source: systematized by the authors 


\section{ENTREPRENEURSHIP AND SUSTAINABILITY ISSUES}

ISSN 2345-0282 (online) http://jssidoi.org/jesi/

2021 Volume 8 Number 4 (June)

http://doi.org/10.9770/jesi.2021.8.4(46)

Small business not only ensures the development of the national economy on an innovative basis, but also helps to reduce social tensions in society by overcoming a number of pressing social problems, including unemployment as a result of increasing the number of new jobs. It is possible to increase the level of employment of population in small business entities under condition of increasing the number of jobs at the cost of newly created small business entities, as well as through increasing the number of employees in existing economic entities.

Studies of the actual needs of employers in employees to fill vacancies and their declared needs according to the reporting of employment centers showed their inconsistency due to failure to provide information on the need in employees to employment services. Small business entities note the low efficiency of recruitment through employment centers, extending the search for staff over time, the lack of highly qualified staff registered in district employment centers. When selecting staff to fill vacancies, small businesses are mainly focused on their own options. Staff search is carried out by means of advertisements on the Internet and in periodicals (specialized newspapers and magazines). The services of recruitment agencies are too expensive for small business entities, so they are not in demand among this type of economic entities.

The problem of legalization of employment of population in Ukraine is extremely urgent at the present stage of development of the domestic economy. As a result of informal employment, the budget loses money in the form of unpaid taxes by both employers and employees, and citizens who agree to informal employment are deprived of social guarantees. Registration of labor relations in the order established by law, the official receipt of wages ensure state protection against illegal dismissal of an employee, safe working conditions, guaranteed right to rest, timely paid legal wages, pension insurance record and the opportunity to have a decent pension support when a worker reaches retirement age.

It should be noted that the most effective ways to promote legalization of employment of population in Ukraine are to optimize the minimum wage, reduce its taxation, increase liability for violations of labor laws, increase funding for active measures to promote employment of population and small business development.

Studies of the policy of employment of population in small business have shown a distortion of the structure of employment towards certain economic activities, in particular the prevalence of employment of population in wholesale and retail trade over employment in other areas of economic activity.

The above proves the need to introduce measures to stimulate small business and employment of population in other areas of economic activity, in particular, in agriculture, forestry and fishery; health care; arts, sports, entertainment and recreation, where the lowest employment rates are observed, $2 \%, 1 \%$ and $0.8 \%$, respectively, in the general structure of employment in small business.

A separate direction of increasing the level of employment of population in small business is the development and implementation of the state program to prevent unemployment, ensuring a downward trend in unemployment at the cost of small business entities through stimulation of the latter, improving the efficiency of regional employment services to find and replace vacancies.

Given the results of scientific studies, it is possible to draw a conclusion on the key role of small business in solving the problem of unemployment and labor migration.

In general, in 2019, in Ukraine there was recorded an increase in migration in the volume of 10,143 of cases. It should be noted that official statistics do not give us a clear idea of the real scale of external labor migration. According to different national and international institutions, the number of migrant workers ranges from 865,000 to $6.5 \mathrm{mln}$ in 2018. In this case, the values of the volume of labor migration beyond the lower limit of the range 
ENTREPRENEURSHIP AND SUSTAINABILITY ISSUES

ISSN 2345-0282 (online) http://jssidoi.org/jesi/

2021 Volume 8 Number 4 (June)

http://doi.org/10.9770/jesi.2021.8.4(46)

were chosen to build the diagram. This rule also applies to the indicators of all institutions involved for comparison without exception (Figure 1).

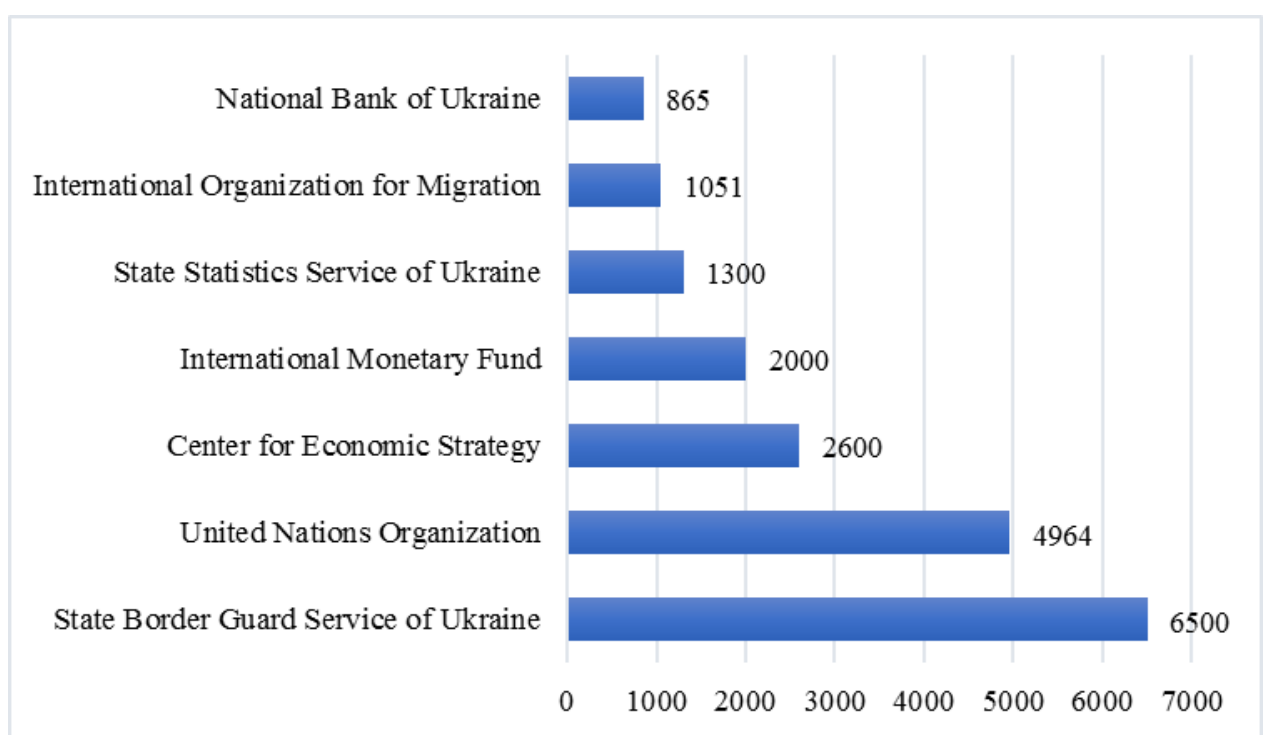

Fig. 1. Number of labor migrants from Ukraine as of the beginning of 2019 according to estimates of leading national and international institutions, mln ppl.

Source: built by the authors according to Population and migration (2020), Labor migration from Ukraine is expected to decline in the medium term (2018), How many Ukrainians went abroad and what should the state do about it (2018), International Monetary Fund.

European Dept. Ukraine: Request for Stand-By Arrangement and Cancellation of Arrangement Under the Extended Fund Facility-Press Release; Staff Report; and Statement by the Executive Director for Ukraine. Country Report (2019), United Nations. Department of Economic and Social Affairs. Population Division. Trends in International Migrant Stock (2017), Last year, 10,000 potential illegal migrants were stopped at the border (2020), Site of International Organization for Migration. One in eight Ukrainians ready to accept a job offer that can lead to exploitation: survey on migration and human trafficking in Ukraine, Moldova, Belarus and Georgia (2019)

It should be noted that most institutions are not able to report the exact number of migrant workers from Ukraine. Thus, according to the State Statistics Service, 1.3-2.3 million people work outside Ukraine. This indicator is calculated on the basis of a survey conducted by the State Statistics Service of Ukraine, which covered 20 thousand households. The obtained results were extrapolated to the entire population of Ukraine using the methodology of the International Labor Organization. The figure of $1.3 \mathrm{mln} \mathrm{ppl}$ is understated due to the fact that it includes only the contingent of workers who went abroad for a short time and long-term migrants with families in Ukraine.

Migrant workers who left with their families, as well as those who did not have a family in Ukraine at all, are not included in the sample (Population and migration (2020)), according to the National Bank of Ukraine (NBU), it is from 0.865 to $1.384 \mathrm{mln}$ ppl, which is $5 \%-8 \%$ of the total labor force calculated according to the number of the working population of Ukraine in 2018 (Labor migration from Ukraine is expected to decline in the medium term (2018)); according to the non-governmental research center for the issues of economic policy - the Center for Economic Strategy (CES), the number of migrant workers from Ukraine in 2018 was about $4 \mathrm{mln}$ ppl, but the number of workers who are simultaneously outside the country is much smaller and ranges from 2.6 to $2.7 \mathrm{mln}$ ppl (How many Ukrainians went abroad and what should the state do about it (2018)); the International Monetary Fund estimates the number of labor migrants from Ukraine at 2-3 mln ppl (International Monetary Fund. European Dept. Ukraine: Request for Stand-By Arrangement and Cancellation of Arrangement Under the Extended Fund Facility-Press Release; Staff Report; and Statement by the Executive Director for Ukraine. Country Report (2019)). 


\section{ENTREPRENEURSHIP AND SUSTAINABILITY ISSUES}

ISSN 2345-0282 (online) http://jssidoi.org/jesi/

2021 Volume 8 Number 4 (June)

http://doi.org/10.9770/jesi.2021.8.4(46)

In 2019, the annual volume of external labor migration from Ukraine is 100 thousand people per month, which corresponds to the intensity of the migration flow of 2 people per minute. Since 2010, about 4 million citizens have left Ukraine, which is about $10 \%$ of the population.

In Ukraine, small business entities are an underestimated reserve for employment growth both due to the increase in the number of self-employed persons and due to the jobs they create for employees. As of the beginning of $2019,99.1 \%$ of all national business entities are represented by SBEs. It should be noted that the number of hired workers in SBEs has decreased over the past 9 years. In 2018, it amounted to $85.8 \%$ of the indicator of 2010, which corresponds to the value of 2,603,135 people. A similar negative trend is observed for workers employed at the cost of SBEs. During 2010-2018, their number decreased by $15.8 \%$ amounting to 4,173,665 people.

Indicators of the number of employed and hired employees in SBEs indirectly reflect the state and trends of small business development in Ukraine. The decrease in employment of population at the cost of SBEs in the period proves the fact of worsening business environment for this group of business entities.

At present, Ukraine is undergoing significant reforms focused on creation of a favorable environment for the operation of SBEs and deregulation of their economic activities, in particular, removing administrative barriers, eliminating unnecessary administrative procedures, bringing regulations in line with the laws of Ukraine and international legal obligations, reforming the permit system, licensing, state supervision and control bodies, maximum simplification of business conditions, compliance with the principle of transparency and consideration of public opinion.

Ensuring the transition of Ukraine to sustainable economic development requires the fulfillment of key conditions, such as: a decent standard of living, education, equality, long and healthy life, favorable economic and environmental conditions. But the realities show that in 2019 in Ukraine the human development index (0.75) was below the average for countries with a high level of human development (0.755) and the average for Europe and Central Asia (0.758) (Human Development Report for 2019 (2020)). As life expectancy depends on confidence in the stability of one's life, which is ensured, in particular, by the availability of a job and the timely payment of wages, in Ukraine, unfortunately, poverty remains one of the main problems of development of the country today.

It should be noted that intensification of the process of creation of new jobs is an important basis for achieving above conditions, which is constantly due to the growth and improvement of production, its structural changes in accordance with market requirements. Without the creation of new jobs, it is impossible to optimize the production employment of able-bodied citizens in society, which is an important factor in improving both production efficiency and living standards. The increase in employment is also reflected in the level of total income of the population, at the expense of which it is possible to meet the needs in payment for medical services, education, purchase of food, recreation, etc.

Thus, given the limited employment opportunities, rising unemployment, small business can significantly alleviate existing social problems. Activization of the use of the potential of small business to create new jobs and absorb surplus labor during cyclical downturns and structural shifts in the economy should be an important precondition for sustainable economic growth.

In terms of the effectiveness of the innovation process, small business entities have a number of advantages over large and medium-sized enterprises, namely: they have a higher level of mobility, respond quickly to changes in market situation due to small volumes of production and sales and, as a result, have lower risks of losses related with the transition to new technologies. The absence of complex management structures increases the efficiency of management of small business entities, which, in turn, contributes to the rapid improvement and 
implementation of technologies. Small business shows high resilience in difficult conditions of adaptation to market conditions, which allows it to be a loyal and long-term consumer of advanced technologies.

Creation of business incubators is one of the promising areas of promoting the development of national small business. Business incubators ensure the effective transformation of existing intellectual products in the regions into competitive products and services, stimulate real investment of private capital in innovation, help increase the export potential of national knowledge-intensive high-tech products. As international practice has shown, the most successful models of business incubators are American, European and Asian ones. According to the results of conducted studies (The Global Innovation Index (GII) (2020)), about $30 \%$ of economic entities continue their activities after the first year of operation, and among the clients of business incubators, this figure reaches $80 \%$, which indicates the feasibility of participating in incubation.

In 2019, Ukraine ranked 47th in the overall ranking of the Global Innovation Index (37.40 points of 100) losing 5 points over the past 7 years. In 2013, Ukraine ranked 42nd in the overall ranking of the Global Innovation Index. As of 2019, Switzerland ranked first, Sweden ranked second, and the USA ranked third. It was calculated according to the methodology of INSEAD international business school based on 82 variables (The Global Innovation Index (GII) (2020)).

It is worth noting that for the last four years there has been a decrease in the share of innovative industrial enterprises in Ukraine. Compared to 2016, their share decreased by $3.1 \%$ (Figure 2).

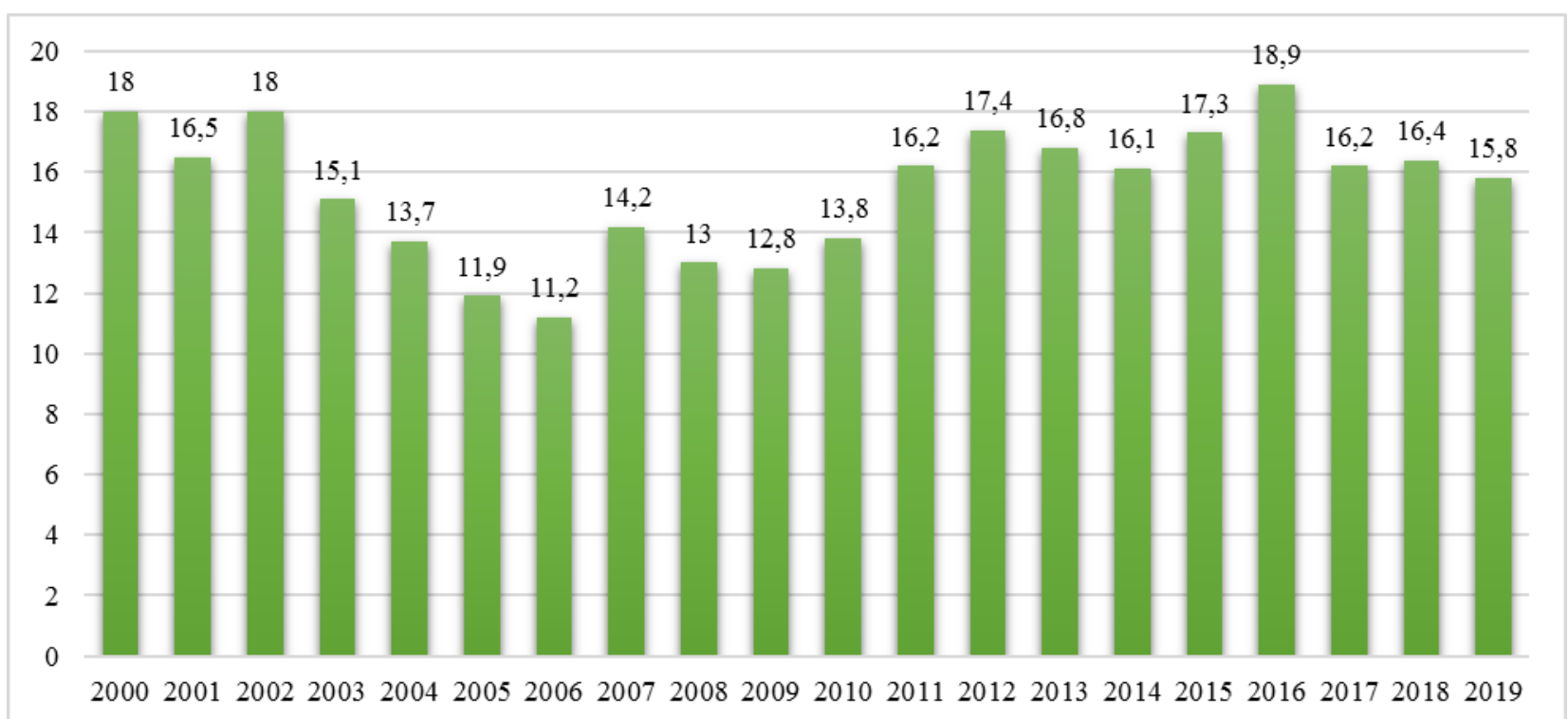

Fig. 2. Share of the number of innovatively active enterprises in the total number of industrial enterprises in the country during 2000-2019, $\%$.

Source: built by the authors according to Expenditures on innovation of industrial enterprises by areas of innovation activity (2020)

Regarding expenditures on innovation, their largest share is accounted for by purchase of machinery, equipment and vehicles: from $54.8 \%$ to $85.3 \%$ during $2000-2019$. There is a positive trend of increasing the share of R\&D expenditures from $15.1 \%$ in 2000 to $20.5 \%$ in 2019 , although in the last year the situation with R\&D is not so optimistic. There is a decrease in the share of R\&D expenditures by $5.8 \%$ (Figure 3). 


\begin{tabular}{|c|c|c|c|c|}
\hline \multicolumn{5}{|c|}{ Other expenses } \\
\hline \multicolumn{5}{|c|}{ Purchase of machinery, equipment and software } \\
\hline \multicolumn{5}{|c|}{ Acquisition of other external knowledge } \\
\hline \multicolumn{5}{|c|}{ Research and Development (R\&D) } \\
\hline & & $0 \Omega$ & & \\
\hline & $\begin{array}{l}\text { Research and Development } \\
(\mathrm{R} \& \mathrm{D})\end{array}$ & $\begin{array}{c}\text { Acquisition of other external } \\
\text { knowledge }\end{array}$ & $\begin{array}{l}\text { Purchase of machinery, } \\
\text { equipment and software }\end{array}$ & Other expenses \\
\hline 2007 & 9,1 & 3,0 & 68,8 & 19,1 \\
\hline 2008 & 10,4 & 3,5 & 63,9 & 22,2 \\
\hline 2009 & 10,7 & 1,4 & 62,6 & 25,3 \\
\hline 2010 & 12,4 & 1,7 & 62,8 & 23,1 \\
\hline — 2011 & 7,5 & 2,3 & 73,2 & 17,0 \\
\hline 2012 & 10,4 & 0,4 & 70,1 & 19,1 \\
\hline - 2013 & 17,1 & 0,9 & 58,0 & 24,0 \\
\hline - 2014 & 22,8 & 0,6 & 66,5 & 10,1 \\
\hline — 2015 & 14,8 & 0,6 & 80,6 & 4,0 \\
\hline — 2016 & 10,6 & 0,3 & 85,3 & 3,8 \\
\hline — 2017 & 23,8 & 0,2 & 64,7 & 11,3 \\
\hline — 2018 & 26,3 & 0,4 & 68,1 & 5,2 \\
\hline 2019 & 20,5 & 0,3 & 71,6 & 7,6 \\
\hline
\end{tabular}

Fig. 3. Share of expenditures on innovation of industrial enterprises by areas of innovation activity during 2007-2019, $\%$. Source: built by the authors according to Expenditures on innovation of industrial enterprises by areas of innovation activity (2020)

It should be noted that as of $201915.8 \%$ of national economic entities were engaged in innovation activities. $2 \%$ fewer enterprises implemented innovations. The share of the volume of sold innovative products is at all insignificant. In 2019, it corresponded to the value of $1.3 \%$ of the total volume of products sold by industrial enterprises. According to sample surveys, the share of national innovatively active small business entities does not exceed $18.4 \%$, which is due to the influence of a number of restraining factors, such as: financing problems (lack of own funds, difficulty in attracting financial resources from market sources: strict credit conditions, insufficient financial support from the state, the difficulty of attracting investors); immaturity of innovation infrastructure; imperfection of the technology market; lack of systematic information regarding the condition and forecast assessment of the market of innovative products; low level of innovation potential of small business entities; high probability of risks from the implementation of innovative activities; low effective demand for Ukrainian innovative products.

According to the results of the state statistical survey "Survey of innovation activity of industrial enterprises" (2015), for national economic entities, own funds are the main source of financing of innovation expenditures: as of the end of 2019, this indicator reaches UAH 12,474.9 mln (87.7\% in the cost structure). It should be noted that the volume of foreign investment corresponds to UAH $42.5 \mathrm{mln}$ or $0.3 \% ; 3.9 \%$ are provided by state and local budgets; $8.1 \%$ are funds coming from other sources. Thus, the financing of innovation expenditures is one of the most pressing issues of national small business entities, given their limited ability to finance innovation costs from their own funds. 


\section{ENTREPRENEURSHIP AND SUSTAINABILITY ISSUES}

ISSN 2345-0282 (online) http://jssidoi.org/jesi/

2021 Volume 8 Number 4 (June)

http://doi.org/10.9770/jesi.2021.8.4(46)

\section{Discussion}

The use of the principles of business economics, among which the principle of effective interaction of large and small business is important, is one of the key conditions for sustainable development and integration of the modern economic system of Ukraine into the world economic system.

It should be noted that in the difficult conditions of globalization, the selection of the European path of development and accession of Ukraine to the World Trade Organization, representatives of Ukrainian business behave differently. Large corporations enter international markets, participate in the internationalization of high technologies. Medium-sized enterprises are more focused on the domestic market and depend on the economic policy pursued by the state.

Small enterprises are mostly connected with local markets, cover almost all areas of production of goods and services at the regional and domestic levels, have high level of adaptability and are most interested in the policy of effective government regulation and business support, creation of a favorable business environment. But at the same time, both large corporations and medium and small enterprises work closely together.

Thus, in our opinion, intensification of the interaction of small, medium and large enterprises, i.e. their economic integration, should be one of the ways to address the issues of development of small business and increase the efficiency of its potential, which will contribute to the development of small business entities in a crisis, increase in production and sales of its products and services, extension of the life cycle of a business and provision of its sustainable operation as a competitive business entity.

In turn, large enterprises also expect positive results from this cooperation, including: minimization of the number of production and sales operations, which affects the reduction of costs, the process cycle and the price of manufactured products (Belitski et. al (2019)).

Therefore, based on the above, we can draw a general conclusion that the integration of small, medium and large business should be considered a business association of commercial and non-profit organizations and individual businessmen interacting in the process of creation and sale of products (services) and related integration relations as:

- members of business associations can be commercial and private non-profit organizations, including those that successfully carry out their activities in the field of social services;

- product-commodity is, as a rule, the unifying feature of integration production associations;

- integration interactions of participants are not limited to participation in the authorized capital, implementation of targeted programs, but cover all areas and directions of their cooperation.

Since in the economy integration of small, medium and large enterprises is a controlled process of their interaction, which has organizational-management, production-technological, and economic-legal aspects, the structure of business associations should be divided into partnership and management forms. As a result of a low level of capitalization of small enterprises, their participation in partnership forms of integration is limited and may not always give the expected result.

Management forms of integration, which include network and cluster subtypes, are more attractive to small business entities. Thus, there have become widespread such forms of production functional integration relations as subcontracting. In production and sales relations it is franchising, in production-financial relations it is leasing, and in the area of innovation it is venture financing. 


\section{ENTREPRENEURSHIP AND SUSTAINABILITY ISSUES}

ISSN 2345-0282 (online) http://jssidoi.org/jesi/

2021 Volume 8 Number 4 (June)

http://doi.org/10.9770/jesi.2021.8.4(46)

The positive effect of the operation of business associations is also observed in the development of economies of EU member states. As you know, in the EU member states, small enterprises create $50 \%$ of jobs and account for almost $40 \%$ of sales, while medium-sized enterprises provide employment for $17 \%$ of the able-bodied population and produce almost $18 \%$ of the total volume of sold products (Yan, J., \& Yan, L. (2016)).

Effective use of the potential of small and medium-sized business was facilitated, in addition to significant government support, by their broad interaction with large corporations, when small enterprises act as satellites and ensure the implementation of separate parts of production processes, the manufacture of small-scale products to ensure the activities of large enterprises. Active participation of small and medium-sized enterprises in industrial production characterizes the innovative orientation of business development in the countries of the European Union (Burch et. al (2016)).

It should be noted that the interaction of small and large business, in particular, is necessary when placing orders for the production of some parts, which are needed by large companies, in small enterprises. Many large corporations place their orders in small enterprises located in less developed countries, which helps to save money of the companies and replenish the budgets of these countries. This is the principle of many large enterprises engaged in the production of consumer electronics, clothing, footwear.

Moreover, the potential of a small enterprise can be used in software development, software application testing, and in the organization of service of products manufactured by large enterprises. Successful large companies prefer not to keep system administrators on the payroll and instead conclude agreements with small enterprises for the maintenance of computers and office equipment.

\section{Conclusions}

Among the main strategic priorities for economic growth, modernization of regional development of Ukraine is the shift of emphasis on the identification of the internal potential of the regions, the introduction of effective mechanisms and tools to stimulate local and regional development, intensification of business activity. Therefore, identifying ways to improve the efficiency of small business potential as an important structural element of the economic system is one of the preconditions for sustainable economic growth.

Based on the the characteristics and specifics of economic activity of national small business entities previously substantiated in the paper, as well as taking into account the negative trend of recent years to reduction of their innovation activity, the innovative dominants of development were formed: improving the process of conducting statistical surveys and recording indicators of innovation activity separately for SBEs; formation of innovation policy for the small business sector at all levels of government; introduction in the national program of small business of the section on development of innovative activity with the substantiation of priority of its areas and volumes of the financial means necessary for ensuring financial-credit support of SBEs; further development of innovation infrastructure; tax incentives for innovative activity of small business enterprises.

Improvement of the organizational and economic relations of small enterprises with large and medium enterprises was determined as one of the directions of increasing the efficiency of small business potential, and the formation of an integration model of business associations as a set of possible forms of interaction of small, medium and large enterprises and areas of integration was suggested taking into account the level of small business capacity and its activity regarding the operation of these forms in ensuring more efficient use of its potential.

Among the most attractive and possible areas of economic integration of production activities with large companies where small business can intensify the use of its potential, there were identified production- 


\section{ENTREPRENEURSHIP AND SUSTAINABILITY ISSUES}

ISSN 2345-0282 (online) http://jssidoi.org/jesi/

2021 Volume 8 Number 4 (June)

http://doi.org/10.9770/jesi.2021.8.4(46)

technological, scientific-technical and economic-legal areas of their interaction, within which such forms of cooperation as franchising, leasing, clusters, industrial parks and others can be used.

\section{References}

Alsafadi, Y., Aljawarneh, N., Çağlar, D., Bayram, P., \& Zoubi, K. (2020). The mediating impact of entrepreneurs among administrative entrepreneurship, imitative entrepreneurship and acquisitive entrepreneurship on creativity. Management Science Letters, 10(15), 35713576. Retrieved from: http://m.growingscience.com/beta/msl/4069-the-mediating-impact-of-entrepreneurs-among-administrativeentrepreneurship-imitative-entrepreneurship-and-acquisitive-entrepreneurship-on-creativity.html

Amato, C., Baron, R. A., Barbieri, B., Belanger, J. J., \& Pierro, A. (2017). Regulatory modes and entrepreneurship: the mediational role of alertness in small business success. Journal of Small Business Management, 55, 27-42. Retrieved from: https://onlinelibrary.wiley.com/doi/abs/10.1111/jsbm.12255

Audretsch, D. B., Heger, D., \& Veith, T. (2015). Infrastructure and entrepreneurship. Small Business Economics, 44(2), 219-230. Retrieved from: https://link.springer.com/article/10.1007/s11187-014-9600-6

Audretsch, D. B., Kuratko, D. F., \& Link, A. N. (2015). Making sense of the elusive paradigm of entrepreneurship. Small Business Economics, 45(4), 703-712. Retrieved from: https://link.springer.com/article/10.1007/s11187-015-9663-Z

Baker, H. K., Kumar, S., \& Pandey, N. (2021). Thirty years of Small Business Economics: A bibliometric overview. Small Business Economics, 56(1), 487-517. Retrieved from: https://link.springer.com/article/10.1007/s11187-020-00342-y

Belitski, M., Caiazza, R., \& Lehmann, E. E. (2019). Knowledge frontiers and boundaries in entrepreneurship research. Small Business Economics, 1-11. Retrieved from: https://link.springer.com/content/pdf/10.1007/s11187-019-00187-0.pdf

Burch, S., Andrachuk, M., Carey, D., Frantzeskaki, N., Schroeder, H., Mischkowski, N., \& Loorbach, D. (2016). Governing and accelerating transformative entrepreneurship: exploring the potential for small business innovation on urban sustainability transitions. $\begin{array}{llllll}\text { Current } \quad \text { opinion } & \text { in } & \text { 26 } & \text { 26-32. } & \text { Retrieved }\end{array}$ https://www.sciencedirect.com/science/article/abs/pii/S1877343517300581

Canales, R. (2016). From ideals to institutions: Institutional entrepreneurship and the growth of Mexican small business finance. Organization Science, 27(6), 1548-1573. Retrieved from: https://pubsonline.informs.org/doi/abs/10.1287/orsc.2016.1093

Colpan, A. M., \& Jones, G. (2016). Business groups, entrepreneurship and the growth of the Koç Group in Turkey. Business History, 58(1), 69-88. Retrieved from: https://www.tandfonline.com/doi/abs/10.1080/00076791.2015.1044521

Dana, L. P. (2017). International entrepreneurship research: how it evolved and directions for the future. International Journal of $\begin{array}{llllll}\text { Entrepreneurship and } \quad \text { Small } & \text { Business, } & \text { 30(4), } & \text { Retrieved }\end{array}$ https://www.inderscienceonline.com/doi/abs/10.1504/IJESB.2017.082889

Economic Code of Ukraine. With amendments (2003). Resolution of the Verkhovna Rada No. 436-IV, January 14, 2003. Retrieved from: https://zakon.rada.gov.ua/laws/show/436-15

Expenditures on innovation of industrial enterprises by areas of innovation activity (2020). State Statistics Service of Ukraine. Retrieved from: http://www.ukrstat.gov.ua/operativ/operativ2020/ni/vut_ippni/vut_ippni_u.htm

Henrekson, M., \& Sanandaji, T. (2020). Measuring entrepreneurship: do established metrics capture Schumpeterian entrepreneurship?. Entrepreneurship Theory and Practice, 44(4), 733-760. Retrieved from: https://journals.sagepub.com/doi/abs/10.1177/1042258719844500 https://journals.sagepub.com/doi/abs/10.1177/0266242617719314

How many Ukrainians went abroad and what should the state do about it (2018). Center for Economic Strategy website. Retrieved from: https://ces.org.ua/migration/

Human Development $\quad$ Report $\quad$ for $\quad 2019 \quad$ (2020). $\quad$ Retrieved https://www.undp.org/content/dam/ukraine/docs/HDR/hdr_2019_overview___ukrainian.pdf 


\section{ENTREPRENEURSHIP AND SUSTAINABILITY ISSUES}

ISSN 2345-0282 (online) http://jssidoi.org/jesi/

2021 Volume 8 Number 4 (June)

http://doi.org/10.9770/jesi.2021.8.4(46)

International Monetary Fund. European Dept. Ukraine: Request for Stand-By Arrangement and Cancellation of Arrangement Under the Extended Fund Facility-Press Release; Staff Report; and Statement by the Executive Director for Ukraine. Country Report (2019).

Labor migration from Ukraine is expected to decline in the medium term (2018). National Bank of Ukraine. Retrieved from: https://bank.gov.ua/admin_uploads/file/Interview\%20Nikolaichuk_Polish\%20media_PAP_2018_02_22.pdf

Last year, 10,000 potential illegal migrants were stopped at the border (2020). State Border Guard Service of Ukraine. Retrieved from: https://dpsu.gov.ua/ua/news/torik-na-kordoni-zavernuli-10-tisyach-potenciynih-nezakonnih-migrantiv

Newman, A., Schwarz, S., \& Ahlstrom, D. (2017). Microfinance and entrepreneurship: An introduction. International Small Business Journal, 35(7), 787-792. Retrieved from: https://journals.sagepub.com/doi/abs/10.1177/0266242617719314

On state support of small business. With amendments (2000). Resolution of the Verkhovna Rada No. 2063-III, October 19, 2000. Retrieved from: https://zakon.rada.gov.ua/laws/show/2063-14\#Text

Population and migration (2020). State Statistics Service of Ukraine. Retrieved from: http://www.ukrstat.gov.ua/druk/publicat/kat u/publnasel u.htm

Retrieved from: $\quad$ https://www.imf.org/en/Publications/CR/Issues/2019/01/08/Ukraine-Request-for-Stand-By-Arrangement-andCancellation-of-Arrangement-Under-the-Extended-46499

Staniewski, M. W. (2016). The contribution of business experience and knowledge to successful entrepreneurship. Journal of Business Research, 69(11), 5147-5152. Retrieved from: https://www.sciencedirect.com/science/article/abs/pii/S0148296316302582

Site of International Organization for Migration. One in eight Ukrainians ready to accept a job offer that can lead to exploitation: survey on migration and human trafficking in Ukraine, Moldova, Belarus and Georgia (2019). Retrieved from: http://ukrame.iom.int/sites/default/filesiom_regional_ct_survey_2019_eng_print.pdf

Survey of innovation activity of industrial enterprises (2015). State Border Guard Service of Ukraine. Retrieved from: https://ukrstat.org/uk/metaopus/2015/1-2 $07 \quad 02 \quad 01 \quad 2015 . h t m$

Summers, D. (2015). The economic impact of entrepreneurship: Setting realistic expectations. Academy of Entrepreneurship Journal, 21(2), 99. Retrieved from: https://search.proquest.com/openview/9aece2114e79e8f88ee70aa782904c7e/1 ? pq-origsite=gscholar\&cbl=29726

Tax Code of Ukraine. With amendments (2011). Resolution of the Verkhovna Rada No. 436-IV, December 22, 2011. Retrieved from: https://zakon.rada.gov.ua/laws/show/2755-17\#Text

The Global Innovation Index (GII) (2020). Retrieved from: https://www.globalinnovationindex.org/Home

United Nations. Department of Economic and Social Affairs. Population Division. Trends in International Migrant Stock (2017). Retrieved from: https://www.un.org/en/development/desa/population/migration/data/estimates2/docs/MigrationStockDocumentation_2017.pdf

Yan, J., \& Yan, L. (2016). Individual entrepreneurship, collective entrepreneurship and innovation in small business: an empirical study. International Entrepreneurship and Management Journal, 12(4), 1053-1077. Retrieved from: https://link.springer.com/article/10.1007/s11365-015-0380-5 
Irina SKURATOVYCH, Ph.D in Law, Associate Professor, Yaroslav Mudryi National law University ORCID ID: orcid.org/0000-0002-1355-7022

Nataliia LYTVYN, Doctor of Law, Professor, Professor Department of Administrative Law and Process and Customs Security, State Fiscal Service University of Ukraine

ORCID ID: orcid.org/0000-0003-4199-1413

Iryna PANOVA, Ph.D. in Law, Associate Professor, Head of the Department of Law Enforcement Activity and Policeistics, Kharkiv National University of Internal Affairs

ORCID ID: orcid.org/0000-0003-4325-5428

Ievgen OVCHARENKO, D. Sc. (Economics), Professor, Volodymyr Dahl East Ukrainian National University

ORCID ID: orcid.org/0000-0001-5267-5067

Olena HRYHOREVSKA, PhD in Economics, Associate Professor, Kyiv National University of Technology and Design

ORCID ID: orcid.org/0000-0001-8279-3523

Make your research more visible, join the Twitter account of ENTREPRENEURSHIP AND SUSTAINABILITY ISSUES: @Entrepr69728810

Copyright (C) 2021 by author(s) and VsI Entrepreneurship and Sustainability Center

This work is licensed under the Creative Commons Attribution International License (CC BY).

http://creativecommons.org/licenses/by/4.0/

c) (†) Open Access 